Research Paper: Immunology

\title{
Peripheral blood microRNAs expression is associated with infant respiratory syncytial virus infection
}

\author{
Shouyi Wang1, Pin Liu ${ }^{1}$, Pu Yang ${ }^{1}$, Junwen Zheng ${ }^{1}$ and Dongchi Zhao ${ }^{1}$ \\ ${ }^{1}$ Department of Pediatrics, Children's Digital Health and Data Center, Zhongnan Hospital of Wuhan University, Wuhan, China \\ Correspondence to: Dongchi Zhao, email: zhao_wh2004@hotmail.com \\ Keywords: respiratory syncytial virus, peripheral blood, miRNA, infants, inflammatory response, Immunology and Microbiology Sec- \\ tion, Immune response, Immunity \\ Received: July 10,2016 Accepted: June 27, $2017 \quad$ Published: July 18, 2017
}

Copyright: Wang et al. This is an open-access article distributed under the terms of the Creative Commons Attribution License 3.0 (CC BY 3.0), which permits unrestricted use, distribution, and reproduction in any medium, provided the original author and source are credited.

\section{ABSTRACT}

MicroRNAs respond to the inflammatory responses induced by RNA virus infection. In this study, we investigated the specific microRNA profile in the peripheral blood of infants infected with respiratory syncytial virus (RSV). Blood specimens were analyzed using microRNA microarrays, followed by quantitative RT-PCR. A specific microRNA profile in the peripheral blood of RSV-infected infants was identified for the first time. MiR-106b-5p, miR-20b-5p, and miR-342-3p were upregulated, while miR-320e, miR-320d, miR-877-5p, miR-122-5p, and miR-92b-5p were downregulated. Pathway analysis indicated that the dysregulated microRNAs were involved in inflammatory and immune responses, including $\mathbf{W n t}$, TGF- $\beta$, insulin, and $T$ and $B$ cell receptor signaling. These results demonstrate that $\mathrm{RSV}$ infection associates with a distinct microRNA fingerprint and suggest that RSV induces inflammatory responses in infants.

\section{INTRODUCTION}

Respiratory syncytial virus (RSV) is an enveloped negative strand RNA virus, which belongs to the Paramyxoviridae family. Infants with RSV infection often develop severe bronchiolitis or pneumonia [1]. The lack of understanding of the host-virus interface has hindered prevention and treatment methods, as well as a successful RSV vaccine development [2]. Even though recent antiviral efforts have begun to inhibit virus replication by targeting host pathways and using interfering RNAs [36], regulation of the host immune responses resulting in bronchiolitis remains a challenge.

Mature microRNAs (miRNA) are non-coding transcripts 18 to 25 nucleotides in length, which modulate protein expression at the post-transcriptional level [7]. The miRNA gene family makes up a global regulatory network controlling homeostasis, cell proliferation, differentiation, cell migration, disease progression, and inflammatory responses [8-10]. Many viruses can make use of the host processing machinery for their biogenesis by encoding miRNAs [11]. Viral infections can also influence host miRNA production. In addition, host miRNAs can regulate the viral life cycle, and target the viral messenger RNA [12].

Recent studies have indicated that miRNAs regulate the inflammatory response associated with RNA virus infection. Let-7c, upregulated in influenza virus-infected epithelium, may inhibit influenza virus replication by directly targeting the viral gene product [13]. RSV nonstructural protein-1 modifies mir-24 expression via transforming growth factor beta (TGF- $\beta$ ) [14]. The lack of downregulation of miR-125a and miR-429 in severe RSV infection may be associated with RSV manifestations [15]. MicroRNA-221 modulates RSV replication in human bronchial epithelium by targeting nerve growth factor expression [16].

Understanding the changes in miRNA expression profiles and identifying the targets genes and their contribution to viral infection may help elucidate novel mechanisms of host-virus interaction [17-18]. In this study, we analyzed the miRNAs fingerprint in whole blood of infants with RSV.

\section{RESULTS}

\section{Clinical characteristics}

Five males and five females were included in the study. The sex ratio was similar in the two sets of samples. 
The diagnosis of RSV infection was based on clinical manifestation, physical signs of lung, laboratory tests, and examination (Table 2). All patient samples were acquired within 7 days of infection onset.

\section{miRNA expression profiles}

Differential expression analysis of miRNA microarrays between RSV patients and healthy controls indicated that 37 miRNAs were upregulated-fold-change $\geq 2$, while 24 miRNAs were downregulated (fold-change $\leq 0.5$ ), and 72 miRNAs (fold-change $=0.5 \sim 2.0$ ) were not changed. The miRNA microarrays analysis data are shown in a hierarchical clustering (Figure 1). From the differentially expressed miRNAs, the top five upregulated miRNAs and six downregulated miRNAs were selected for further validation (Table 3).

\section{qRT-PCR validation of selected miRNAs}

The validation qRT-PCR results are shown in Figures $2 \mathrm{~A}$ and $2 \mathrm{~B}$. Expression of three of the five upregulated miRNAs was significantly different between the RSV group and the control group. However, expression of miR-181a-5p in RSV2, RSV4, RSV5, and miR-652-3p in RSV4 and RSV5 was not consistent with the microarray data. Expression of four of the six downregulated miRNAs (miR-122-5p, miR-320d, miR877-5p and miR-92b-5p) showed a similar trend as that of the microarrays. However, there was no significant change of miR-320e in all five RSV infected cases, and let-7c5 p was downregulated in RSV1, RSV2, and RSV3, while there was no difference in RSV4 and RSV5. These results demonstrated that most qRT-PCR results $(75 \%)$ of miRNA expression were consistent with microarray analyses.
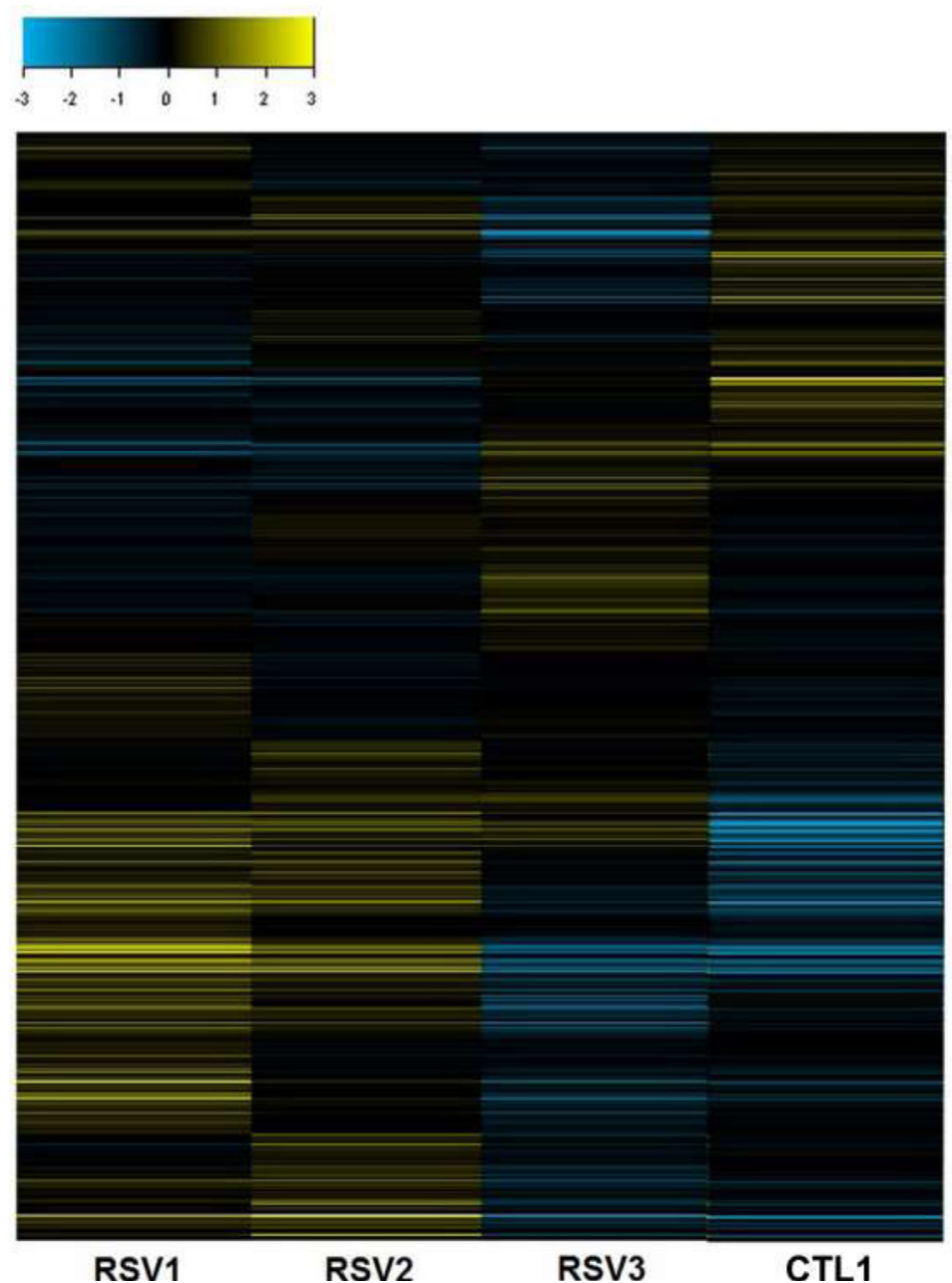

Figure 1: RSV regulated microRNAs expression in peripheral blood. This heat figure was generated using comparison analysis based on signal value ratio method; it provides an overall picture of the impact of RSV infection on the peripheral blood miRNAs as compared to healthy control blood. Data were partitioned between RSV and control (CTL1) samples during the hierarchical clustering and organized into blocks of columns. The rows represent probe sets in each of the arrays, and within each row, the blue shaded areas indicate lower expression of the specific miRNA, whereas the yellow shaded areas indicate higher expression. Black and darkly shaded areas indicate similar expression between infected and non-infected samples. The Euclidean clustering method was used for array data analysis. The expression index is shown in the left upper corner. 
Table 1: Computational algorithms and methods for miRNA target prediction.

\begin{tabular}{|c|c|}
\hline Name & Web link \\
\hline miRanda & http://www.microrna.org \\
\hline TargetScan & http://genes.mit.edu/targetscan \\
\hline PicTar & http://pictar.mdc-berlin.de \\
\hline DIANA-microT & http://diana.pcbi.upenn.edu/cgi-bin/micro_t.cgi \\
\hline RNAhybrid & http://bibiserv.techfak.uni-bielefeld.de/rnahybrid \\
\hline RNA22 & http://cbcsrv.watson.ibm.com/rna22.html \\
\hline PITA & http://genie.weizmann.ac.il/pubs/mir07/mir07_data.html \\
\hline miRDB & http://mirdb.org \\
\hline miRWalk & http://www.ma.uni-heidelberg.de/apps/zmf/mirwalk/ \\
\hline $\begin{array}{l}\text { KEGG } \\
\text { GOmir }\end{array}$ & $\begin{array}{l}\text { http://www.genome.jp/kegg/ } \\
\text { http://www.bioacademy.gr/bioinformatics/projects/GOmir }\end{array}$ \\
\hline
\end{tabular}

Table 2: Clinical characteristics of patients with RSV and healthy controls

\begin{tabular}{|c|c|c|c|c|c|c|c|c|c|c|}
\hline & \begin{tabular}{|l|} 
RSV1 \\
\end{tabular} & RSV2 & RSV3 & \begin{tabular}{|l|l|} 
RSV4 \\
\end{tabular} & \begin{tabular}{|l|l|} 
RSV5 \\
\end{tabular} & CTL1 & CTL2 & CTL3 & CTL4 & CTL5 \\
\hline Gender & male & male & female & female & male & female & male & female & female & male \\
\hline Age (months) & 2.5 & 3.5 & 3.5 & 3 & 7 & 12 & 1 & 1 & 6.5 & 3 \\
\hline Onset time (days) & 3 & 5 & 6 & 4 & 1 & 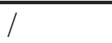 & 1 & 1 & 1 & T \\
\hline $\begin{array}{l}\text { Pulmonary } \\
\text { auscultation }\end{array}$ & wheeze & wheeze & wheeze & wheeze & wheeze & clear & clear & clear & clear & clear \\
\hline $\begin{array}{l}\text { Respiratory rate } \\
\text { (bpm) }\end{array}$ & 38 & 35 & 32 & 34 & 30 & 26 & 35 & 33 & 31 & 30 \\
\hline Oropharyngeal swab & + & + & + & + & + & - & - & - & - & - \\
\hline Chest X-ray & 1 & bronchitis & bronchitis & bronchitis & bronchitis & 1 & 1 & 1 & 1 & 1 \\
\hline $\begin{array}{ll}\begin{array}{l}\text { White } \\
\text { count }\left(10^{9} / \mathrm{L}\right)\end{array} & \text { blood } \\
\end{array}$ & 9.79 & 8.61 & 7.2 & 8.81 & 6.46 & 9.28 & 10.48 & 8.93 & 5.75 & 8.35 \\
\hline $\begin{array}{l}\text { Neutrophil } \\
\text { granulocyte\% }\end{array}$ & 33.1 & 22.8 & 15.4 & 31.3 & 25 & 58.1 & 34.3 & 24.2 & 57.5 & 35.3 \\
\hline Lymphocyte $\%$ & 49.1 & 63.4 & 75.7 & 60.5 & 65.4 & 36.5 & 54.7 & 56.7 & 33.2 & 50.9 \\
\hline
\end{tabular}

\section{Prediction of target miRNAs function}

By using ten different algorithms DIANAmT, miRanda, miRDB, miRWalk, RNAhybrid, PICTAR4, PICTAR5, PITA, RNA22, and Targetscan, we obtained a list of genes predicted to be targeted by miR-106b5p, miR-20b-5p, miR-342-3p, miR-122-5p, miR-320d, miR-877-5p, and miR-92b-5p. If one predicted gene was validated by one database/algorithm, it marked one point. The higher the score the gene received, the more reliable it was. Gene ontology (GO) enriched function analysis and KEGG pathway analysis indicated that miR-106b-5p, miR-20b-5p, miR-342-3p, miR-877-5p, miR-122-5p, miR-320d and miR-92b-5p were involved in many common pathways (Table 4). A large number of pathways were associated with inflammatory and immune processes, such as insulin signaling, TGF-beta signaling, Wnt signaling, $\mathrm{T}$ and $\mathrm{B}$ cell receptor signaling, and $\mathrm{Fc}$ epsilon RI signaling pathway. Natural killer cell mediated cytotoxicity was the common pathway of miR-106b-5p, miR-20b-5p, and miR-342-3p.

The common pathways' crosstalk is displayed in Figure 3. There were twelve pathways and sixteen predicted genes in the crosstalk network. MAPK1 was involved in eight pathways, and NFAT5 participated in regulating three pathways. These signaling pathways are involved in inflammation and immune responses, including TGF-beta signaling, Wnt pathway, insulin signaling, Toll-like receptor signaling, $\mathrm{T}$ and $\mathrm{B}$ cell receptor signaling, and Fc epsilon RI signaling pathway.

\section{DISCUSSION}

In this study, miRNA expression profiles were analyzed in peripheral blood of infants with acute RSV infection, and differential expression of miR-106b-5p, miR-20b-5p, miR-342-3p, miR-877-5p, miR-122-5p, miR-320e, miR-320d, and miR-92b-5p was confirmed by qRT-PCR. The function analysis revealed that the miRNAs participate in signaling pathways involved in inflammation and immune responses.

Previous study using nasal mucosal samples showed that RSV-positive infants downregulated miR-34b, miR34c, miR-125b, miR-29c, miR-125a, miR-429 and miR$27 \mathrm{~b}$, and upregulated miR-155, miR-31, miR-203a, miR16 and let-7d [15]. The differential expression of miRNAs in our study may be derived from the different sample site. In addition, clinical samples have a high degree of 

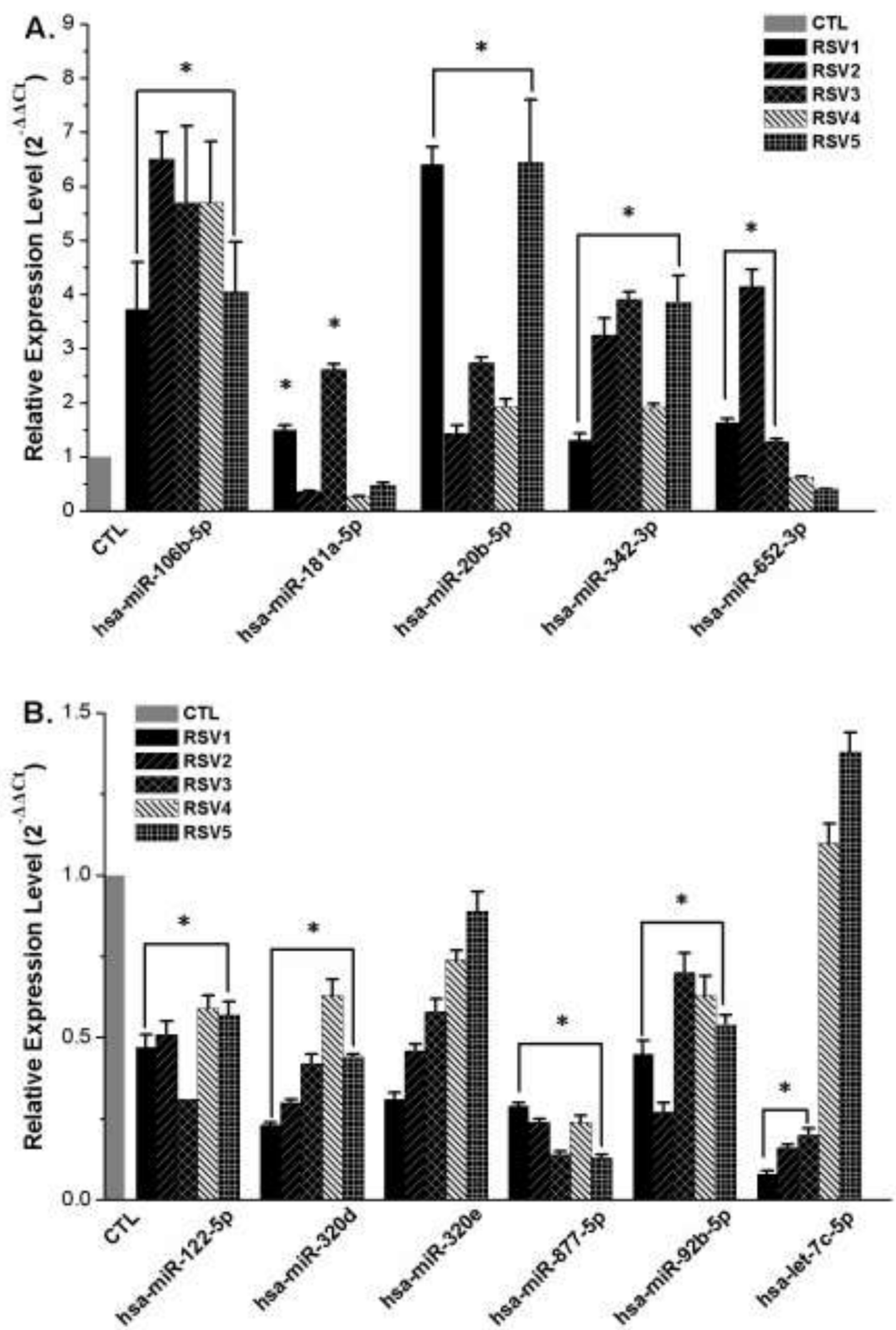

Figure 2: Validation of miRNA microarray findings by quantitative qRT-PCR. Grey column represents miRNAs relative expression level of control samples $\left(2^{-\Delta \Delta \mathrm{C} t}=1.0\right)$. Other color columns represent the selected miRNAs relative levels of each RSV infection sample. A. Relative expression of five upregulated miRNAs (miR-106b-5p, miR-181a-5p, miR-20b-5p, miR-342-3p and miR-652-3p) in microarray. B. Relative expression of six downregulated miRNAs (miR-122-5p, miR-320e, miR-320d, miR-877-5p, miR-92b-5p and let$7 c-5 p)$ in microarray. Asterisk indicates the significant differences between RSV infection and control groups $(P<0.05)$. 
Table 3: Differential expression of microRNAs between RSV and healthy control groups

\begin{tabular}{|l|c|}
\hline \multicolumn{1}{|c|}{ MicroRNAs } & RSV VS CTL (fold-change) \\
\hline hsa-miR-106b-5p & 85.03747 \\
\hline hsa-miR-20b-5p & 67.83043 \\
\hline hsa-miR-181a-5p & 31.82493 \\
\hline hsa-miR-652-3p & 12.15890 \\
\hline hsa-miR-342-3p & 11.55260 \\
\hline hsa-miR-320e & 0.12787 \\
\hline hsa-miR-320d & 0.24643 \\
\hline hsa-miR-877-5p & 0.27453 \\
\hline hsa-miR-122-5p & 0.31253 \\
\hline hsa-miR-92b-5p & 0.35467 \\
\hline hsa-let-7c-5p & 0.36293 \\
\hline
\end{tabular}

$\mathrm{RSV}=$ Respiratory syncytial virus infection sample No.1, 2, 3; $\mathrm{CTL}=$ Control sample. The fold-change of RSV =average fold-change of (RSV1, RSV2, RSV3). Foldchange $\geq 2.0$ indicated upregulation, fold-change $\leq 0.5$ indicated downregulation.

biological variation, and may differ in the miRNA stability as well.

Viral infections can activate the immune system via the activation of pattern recognition receptors (PRRS). RSV proteins and replication products can be recognized by PRRS, resulting in the activation of a series of transcription factors, including $\mathrm{NF}-\kappa \mathrm{B}$, the interferon regulatory factor (IRF)-1, -3 and -7 , and the JAK/STAT signaling pathway [24-26]. Through
KEGG pathway analysis, we found that the JAK-STAT signaling pathway was a common predicted pathway of eight dysregulated miRNAs. In addition, it was shown that RSV could modulate the host innate immune response by dysregulation of host miRNAs related to the antiviral response, a feature that also affects the memory immune response to RSV [27]. The majority of miRNAs dysregulated in our study was involved in pathways related to the immune and inflammatory responses. Among them, the Wnt signaling pathway, TGF- $\beta$ signaling, and insulin signaling are involved in inflammatory responses [28], and $\mathrm{T}$ cell receptor and Fc epsilon RI signaling are involved in immune responses. Almost half of the dysregulated miRNAs belonged to the miR-17-92 family, which is made of the three paralog miR-17-92, miR-106a-363, and miR106b-25 clusters. Notably, miR-106b-5p and miR-20b$5 p$ were from the miR-17 seed family [29]. MicroRNA members of the miR-17-92 family were predicted to target Tgfbr2 mRNA upon iNKT cell development. Increased expression of miR-17-92 suppresses TGF- $\beta$ R II expression and signaling, and activates effector differentiation [30, 31].

Another increased microRNA, miR-342-3p, has been less studied in RSV disease. miR-342-3p is predicted to interact with mRNAs involved in pain signaling, colonic motility, and smooth muscle function [32]. Furthermore, miR-342-3p likely plays a pro-apoptotic role in macrophages through IL-4/STAT6 signaling axis, and provides a negative feedback to IL-4-dependent

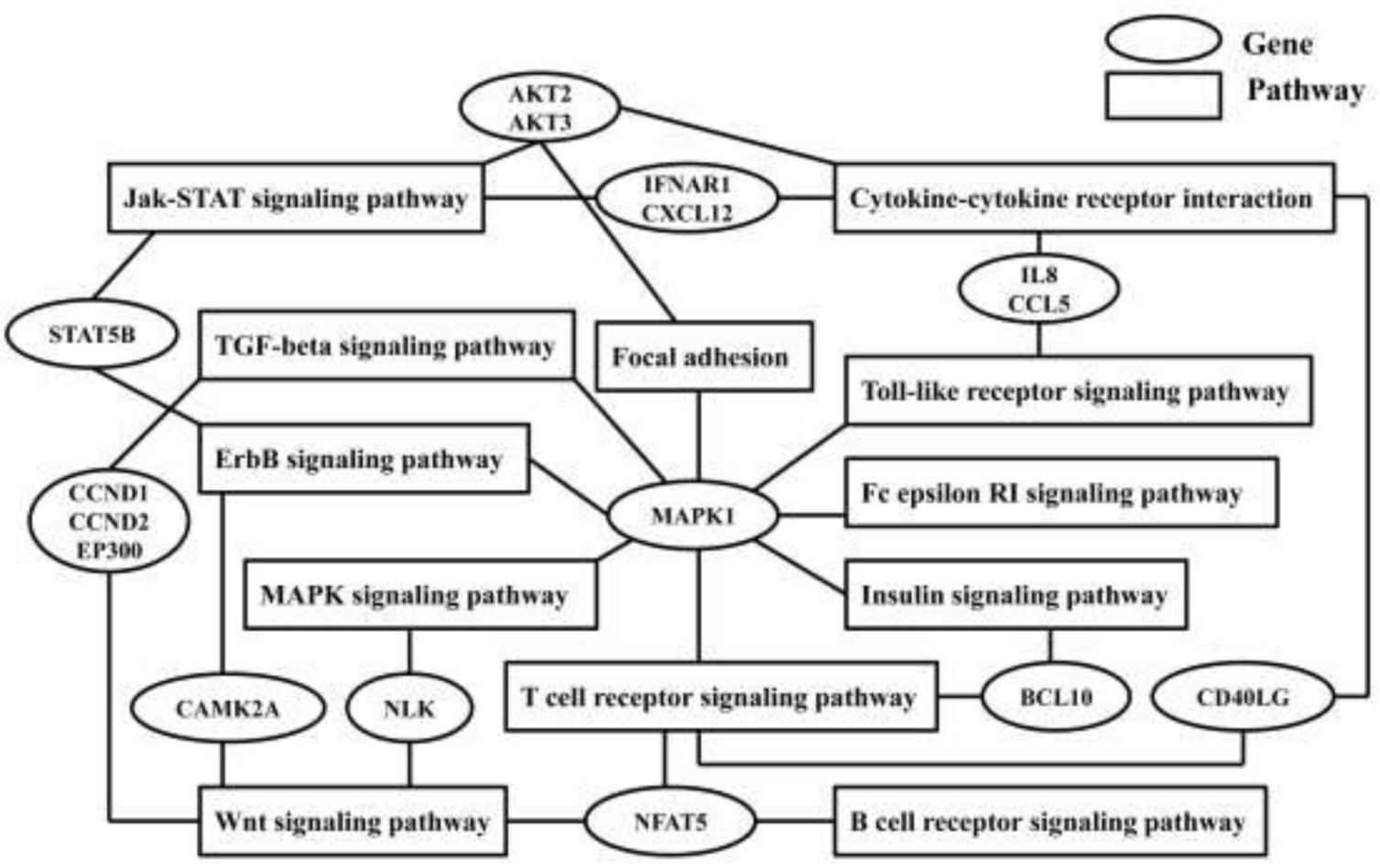

Figure 3: Common genes and relevant pathways' crossing network of seven validated differential expression microRNAs. 
Table 4: Common pathways of seven validated differential expression microRNAs by KEGG analysis

\begin{tabular}{|l|l|l|}
\hline Pathway term & Count & $\boldsymbol{P}$ value \\
\hline Focal adhesion & 35 & $6.42 \mathrm{E}-17$ \\
\hline TGF-beta signaling pathway & 22 & $7.64 \mathrm{E}-15$ \\
\hline T cell receptor signaling pathway & 21 & $9.17 \mathrm{E}-12$ \\
\hline MAPK signaling pathway & 33 & $1.33 \mathrm{E}-11$ \\
\hline ErbB signaling pathway & 17 & $6.83 \mathrm{E}-10$ \\
\hline Wnt signaling pathway & 21 & $5.43 \mathrm{E}-09$ \\
\hline $\begin{array}{l}\text { Leukocyte transendothelial } \\
\text { migration }\end{array}$ & 17 & $1.18 \mathrm{E}-07$ \\
\hline Insulin signaling pathway receptor & 18 & $1.61 \mathrm{E}-07$ \\
\hline $\begin{array}{l}\text { Cytokine-cytokine } \\
\text { interaction }\end{array}$ & 25 & $3.62 \mathrm{E}-07$ \\
\hline Jak-STAT signaling pathway & 14 & $2.30 \mathrm{E}-04$ \\
\hline Toll-like receptor signaling pathway & 10 & $9.27 \mathrm{E}-04$ \\
\hline B cell receptor signaling pathway & 8 & $1.72 \mathrm{E}-03$ \\
\hline Fc epsilon RI signaling pathway & 7 & $9.09 \mathrm{E}-03$ \\
\hline
\end{tabular}

Note: Seven validated differential expression microRNAs were miR-106b-5p, miR-20b-5p, miR-342-3p, miR-877$5 \mathrm{p}$, miR-122-5p, miR-320d and miR-92b-5p. Count: Number of potential target genes in the pathway; $P$ value is significant at the 0.05 level.

macrophage proliferation [33]. However, miR-342-5p is upregulated during antiviral response via the IFN-induced transcription factor IRF1, and exerts broad antiviral effects against viruses, such as cytomegalovirus and Influenza A (H1N1) [34].

Interleukin-1 receptor antagonist (IL1RA) is one of the RSV-induced genes [35]. As a target gene of miR-122$5 p$, interleukin-1 receptor type I (IL1R1) may be activated by increased IL1RA after RSV infection. Toll-like receptor (TLR) 4 is another target gene of miR-122-5p; it is stimulated by the RSV F protein [36]. TLR4-deficient mice infected with RSV exhibit an enhanced disease [3739]. The acute phase of RSV infection induces expression of IL-13, TGF- $\beta$, and IL-6 [40]. The increased production of IL-13 stimulates expression of its receptor IL-13RA1, which further amplifies the Th2 response. Target gene analysis showed that IL-13RA1 is a target gene of miR$877-5$ p. It was also shown that TGF- $\beta$ is a major regulator of human neonatal immune responses following RSV infection [22]. TGFB3 and TGFBR1 involved in TGF- $\beta$ signaling were predicted target genes for miR-877-5p and miR-320d, respectively. Moreover, TGF- $\beta$ and IL- 6 could increase levels of Th17 cells that produce IL-17A, IL-17F, IL-21, and IL-22 [41]. Target gene analysis revealed that several genes associated with Th17 cells: IL-6R, IL-23R, ROR $\gamma$, STAT3, IL-17A, IL-17RE, IL-17RD, CCR4, and CCR6, which belong to miR-122-5p, miR-320d and miR$877-5 \mathrm{p}$.

In conclusion, we found that three miRNAs were upregulated and five miRNAs were downregulated during RSV infection in infants' peripheral blood. However, we did not collect blood specimens during recovery phase of RSV infection, which might better reflect the dynamic regulation of host cell miRNAs. Regardless of this limitation, the present data support the hypothesis that miRNAs are the main regulators of the immune response involved in RSV infection.

\section{MATERIALS AND METHODS}

\section{Subjects}

Five RSV infection children were admitted to Zhongnan Hospital of Wuhan University, Wuhan, China, during the RSV season from December 2014 to March 2015. Healthy controls were five healthy children who received regular development examination. Nasopharyngeal aspirates for virus detection were taken from eligible patients on admission, and the specimens were analyzed using a commercial indirect immunofluorescence (IIF) kit (EUROIMMUN, Lübeck, Germany) following the manufacturer's instructions. Patients with bronchopulmonary dysplasia, chronic lung disease including treated asthma, neurological disease, congenital disorder, hypotonia, failure to thrive, or other specific conditions likely to contribute to a more severe course of disease, were excluded. Whole blood samples were collected within $24 \mathrm{~h}$ after a diagnosis of RSV infection. All blood samples were stored at $-20^{\circ} \mathrm{C}$ within 4 $\mathrm{h}$ following collection prior to analysis for miRNAs.

\section{RNA extraction and quantitation}

Total RNA of peripheral blood (no centrifugation and sedimentation) was extracted by the TRIpure Reagent (BioTeke Corporation, Beijing, China) according to the manufacturer's instructions. Total RNA purification was performed by mirVana ${ }^{\mathrm{TM}}$ miRNA Isolation Kit (AM1561) (Ambion, Austin, TX). RNA quantity and quality were assessed using the NanoDrop ${ }^{\circledR}$ ND-1000 (Thermo Fisher Scientific, Waltham, MA).

\section{MiRNA microarray hybridization}

Three RSV infection samples and one healthy control sample (CTL) were analyzed using miRNA microarrays. The microarray assays were performed by the Affymetrix GeneChip ${ }^{\circledR}$ miRNA 4.0 expression profiling kit at Affymetrix, Inc (Santa Clara, CA). The microarray contained probes for 5214 human miRNAs and generated fluorescent miRNAs with a sample input of $130 \mathrm{ng}$ of total RNA. Labeling was performed using FlashTag ${ }^{\text {TM }}$ Biotin RNA Labeling Kit (Genisphere Inc. Hatfield, PA) containing Poly (A) Tailing and FlashTag 
Ligation. The array hybridization cocktail was prepared. The mixture was incubated at $99^{\circ} \mathrm{C}$ for 5 minutes, then $45{ }^{\circ} \mathrm{C}$ for 5 minutes. Subsequently, the mixtures were transferred to both septa of a microarray slide, and the arrays were placed into hybridization oven and incubated at $48{ }^{\circ} \mathrm{C}$ and $60 \mathrm{rpm}$ for 16 hours. The slides were then washed with washing buffer (Affymetrix Inc, Santa Clara, CA), and scanned immediately by the GeneChip ${ }^{\circledR}$ Scanner 3000 (Affymetrix Inc, Santa Clara, CA). Data collection and quality assessment were performed using Affymetrix ${ }^{\circledR}$ GeneChip ${ }^{\circledR}$ Command Console ${ }^{\circledR}$ Software (Affymetrix Inc, Santa Clara, CA). The signal intensity of individual miRNA probes was expressed as a ratio of the internal control. Microarray results are deposited in the NCBI's Gene Expression Omnibus.

\section{miRNAs for quantitative real-time PCR validation}

miRNAs were selected for further validation and analysis following the criteria of significant differential expression and having predictive target genes in public databases. Five RSV infection and five healthy samples were prepared for selected miRNAs validation by quantitative real-time PCR (qRT-PCR).

Total RNA was purified using mirVana ${ }^{\mathrm{TM}}$ miRNA Isolation Kit (AM1561, Ambion, Austin, TX) and 100 ng per reaction was used for qRT-PCR analysis using the Power SYBR ${ }^{\circledR}$ R Green PCR Master Mix and the 7900 HT Fast RealTime PCR system (Applied Biosystems, CA). All primers (miRNA RT primer \& PCR primers) were synthesized by Invitrogen (Thermo Fisher Scientific Corp., CA). Transcript expression was normalized using mammalian U6 as the endogenous housekeeping gene. QRT-PCR reaction was performed with the following conditions: $95^{\circ} \mathrm{C}$ for $15 \mathrm{~min}$, followed by 40 cycles at $95^{\circ} \mathrm{C}$ for $15 \mathrm{~s}$, and $60{ }^{\circ} \mathrm{C}$ for $60 \mathrm{~s}$, and $60{ }^{\circ} \mathrm{C}$ to $90{ }^{\circ} \mathrm{C}$ for temperature ramp $2 \%$. Samples were analyzed in triplicates, using ABI Prism SDS2.4 software (Thermo Fisher Scientific Corporation, CA). Samples were normalized and calibrated using the $2^{-\Delta \Delta(\mathrm{Ct})}$ method [19].

\section{Bioinformatics analysis}

An extensive analysis of miRNAs target genes was performed by using ten different algorithms DIANAmT, miRanda, miRDB, miRWalk, RNAhybrid, PICTAR4, PICTAR5, PITA, RNA22 and Targetscan (Table 1). The names of miRNAs were put in these databases, if there were predictive target genes of the miRNA in the database, we marked one score, if they were not predictive, we marked zero. The total score was calculated in the end. The higher the score, the more dependable the target gene was. Higher score target genes were selected for performing enriched pathways and functional analysis by the Kyoto encyclopedia of genes and genomes (KEGG) database [20] and Gene ontology miR (GOmir) [21].

\section{Ethics statement}

For de-identification, the blood samples were codified as RSVn (for RSV infection) and CTLn (for healthy controls) to protect the privacy of individuals during all molecular studies. All patients gave informed written consent and the samples were processed under approval from the Zhongnan Hospital of Wuhan University Ethics Committee.

\section{Statistics}

Microarray results were analyzed by the $\mathrm{R}$ computing environment. The Affymetrix ${ }^{\circledR}$ GeneChip $^{\circledR}$ Command Console ${ }^{\circledR}$ Software with quintiles normalization was used for pre-processing. Differential expression analysis of microarray data was assessed using foldchange method [22]. Differential expression miRNA was set by fold-change $\geq 2$ for upper regulation and by fold-change $\leq 0.5$ for downregulation [23]. Cluster data of microarray results were analyzed by hierarchical clustering with pairwise average-linkage approach. PCR results were analyzed using IBM SPSS 20.0 software (Chicago, IL). Adjusted p-values $<0.05$ were considered statistically significant.

\section{ACKNOWLEDGMENTS}

This work was supported by a grant from the National Natural Science Fund 81170005 and 81670007.

\section{CONFLICTS OF INTERESTS}

No potential conflicts of interest.

\section{REFERENCES}

1. Collins PL, Crowe JE. Respiratory syncytial virus and metapneumovirus. In: Fields virology, 5th ed. Knipe DM and Howley PM (ed.) Lippincott Williams \& Wilkins, Philadelphia. 2006; pp1449-1496.

2. Bakre A, Mitchell P, Coleman JK, Jones LP, Saavedra G, Teng M, Tompkins SM, Tripp RA. Respiratory syncytial virus modifies microRNAs regulating host genes that affect virus replication. J Gen Virol. 2012; 93: 2346-56. doi: 10.1099/vir.0.044255-0.

3. Meliopoulos VA, Andersen LE, Birrer KF, Simpson KJ, Lowenthal JW, Bean AG, Stambas J, Stewart CR, Tompkins SM, van Beusechem VW, Fraser I, Mhlanga M, Barichievy S, et al. Host gene targets for novel influenza therapies elucidated by high-throughput RNA interference 
screens. FASEB J. 2012; 26: 1372-86. doi: 10.1096/fj.11193466.

4. Panda D, Das A, Dinh PX, Subramaniam S, Nayak D, Barrows NJ, Pearson JL, Thompson J, Kelly DL, Ladunga I, Pattnaik AK. RNAi screening reveals requirement for host cell secretory pathway in infection by diverse families of negative-strand RNA viruses. Proc Natl Acad Sci U S A. 2011; 108: 19036-41. doi: 10.1073/pnas.1113643108.

5. Yang P, Zheng JW, Wang SY, Liu P, Xie M, Zhao DC. Respiratory syncytial virus nonstructural proteins 1 and 2 are crucial pathogenic factors that modulate interferon signaling and Treg cell distribution in mice. Virology. 2015; 485: 223-32. doi: 10.1016/j.virol.2015.07.016.

6. Zheng JW, Yang P, Tang Y, Pan ZS, Zhao DC. Respiratory Syncytial Virus Nonstructural Proteins Upregulate SOCS1 and SOCS3 in the Different Manner from Endogenous IFN Signaling. J Immunol Res. 2015; 2015: 738547. doi: $10.1155 / 2015 / 738547$.

7. Skalsky RL, Cullen BR. Viruses, microRNAs, and Host Interactions. In: Gottesman S and Harwood CS, eds. Annu Rev Microbiol. 2010; pp. 123-41.

8. Davidson-Moncada J, Papavasiliou FN, Tam W. MicroRNAs of the immune system Roles in inflammation and cancer. In: Rose NR, ed. Year in Immunology 2. 2010; pp. 183-94.

9. Barichievy S, Bakre A. Host-encoded miRNAs involved in host-pathogen interactions (Chapter 6). In: Tripp RA, Karpilow J (eds) Frontiers in RNAi, vol 1. Bentham Science, Sharjah, UAE. 2014; pp. 107-143.

10. Zhang J, Li S, Li L, Li M, Guo CY, Yao J, Mi SL. Exosome and Exosomal MicroRNA: Trafficking, Sorting, and Function. GPB. 2015; 13: 17-24. doi: 10.1016/j. gpb.2015.02.001.

11. Zhou R, Rana TM. RNA-based mechanisms regulating hostvirus interactions. Immunol Rev. 2013; 253: 97-111. doi: 10.1111/imr.12053.

12. Ma YJ, Yang J, Fan XL, Zhao HB, Hu W, Li ZP, Yu GC, Ding XR, Wang JZ, Bo XC, Zheng XF, Zhou Z, Wang SQ. Cellular microRNA let-7c inhibits M1 protein expression of the H1N1 influenza A virus in infected human lung epithelial cells. J Cell Mol Med. 2012; 16: 2539-46. doi: 10.1111/j.1582-4934.2012.01572.x.

13. Song LP, Liu H, Gao SJ, Jiang W, Huang WL. Cellular MicroRNAs Inhibit Replication of the H1N1 Influenza A Virus in Infected Cells. J Virol. 2010; 84: 8849-60. doi: 10.1128/jvi.00456-10.

14. Bakre A, Wu WN, Hiscox J, Spann K, Teng MN, Tripp RA. Human respiratory syncytial virus non-structural protein NS1 modifies miR-24 expression via transforming growth factor-beta. J Gen Virol. 2015; 96: 3179-91. doi: 10.1099/ jgv.0.000261.

15. Inchley CS, Sonerud T, Fjaerli HO, Nakstad B. Nasal mucosal microRNA expression in children with respiratory syncytial virus infection. BMC Infect Dis. 2015; 15: 150. doi: 10.1186/s12879-015-0878-Z

16. Othumpangat $\mathrm{S}$, Walton $\mathrm{C}$, Piedimonte G. MicroRNA-221 Modulates RSV Replication in Human Bronchial Epithelium by Targeting NGF Expression. Plos One. 2012; 7: e30030. doi: 10.1371/journal.pone.0030030.

17. Thornburg NJ, Hayward SL, Crowe JE. Respiratory Syncytial Virus Regulates Human MicroRNAs by Using Mechanisms Involving Beta Interferon and NF-kappa B. Mbio. 2012; 3: e00220-12. doi: 10.1128/mBio.00220-12.

18. Rossi GA, Silvestri M, Colin AA. Respiratory Syncytial Virus Infection of Airway Cells: Role of microRNAs. Pediatr Pulmonol. 2015; 50: 727-32. doi: 10.1002/ ppul.23193.

19. Livak KJ, Schmittgen TD. Analysis of relative gene expression data using real-time quantitative PCR and the 2(T)(-Delta Delta C) method. Methods. 2001; 25: 402-8. doi: 10.1006/meth.2001.1262.

20. Min H, Yoon S. Got target?: computational methods for microRNA target prediction and their extension. Exp Mol Med. 2010; 42: 233-44. doi: 10.3858/emm.2010.42.4.032.

21. Roubelakis MG, Zotos P, Papachristoudis G, Michalopoulos I, Pappa KI, Anagnou NP, Kossida S. Human microRNA target analysis and gene ontology clustering by GOmir, a novel stand-alone application. BMC Bioinformatics. 2009; 10: S20. doi: 10.1186/1471-2105-10-s6-s20.

22. Lockhart DJ, Dong HL, Byrne MC, Follettie MT, Gallo MV, Chee MS, Mittmann M, Wang CW, Kobayashi M, Horton H, Brown EL. Expression monitoring by hybridization to high-density oligonucleotide arrays. Nat Biotechnol. 1996; 14: 1675-80. doi: 10.1038/nbt1296-1675.

23. Patterson TA, Lobenhofer EK, Fulmer-Smentek SB, Collins PJ, Chu TM, Bao WJ, Fang H, Kawasaki ES, Hager J, Tikhonova IR, Walker SJ, Zhang LA, Hurban P, et al. Performance comparison of one-color and two-color platforms within the MicroArray Quality Control (MAQC) project. Nat Biotechnol. 2006; 24: 1140-50. doi: 10.1038/ nbt1242.

24. Openshaw PJ, Tregoning JS. Immune responses and disease enhancement during respiratory syncytial virus infection. Clin Microbiol Rev. 2005; 18: 541-55. doi: 10.1128/ cmr.18.3.541-555.2005.

25. Oshansky CM, Zhang WL, Moore E, Tripp RA. The host response and molecular pathogenesis associated with respiratory syncytial virus infection. Future Microbiol. 2009; 4: 279-97. doi: 10.2217/fmb.09.1.

26. Barik S. Respiratory Syncytial Virus Mechanisms to Interfere with Type 1 Interferons. In: Anderson LJ and Graham BS, eds. Challenges and Opportunities for Respiratory Syncytial Virus Vaccines. 2013; pp. 173-91.

27. Russell CD, Unger SA, Walton M, Schwarze J. The human immune response to respiratory syncytial virus infection. Clin Microbiol Rev. 2017; 30: 481-502. doi: 10.1128/ CMR.00090-16.

28. Vasilescu C, Rossi S, Shimizu M, Tudor S, Veronese A, 
Ferracin M, Nicoloso MS, Barbarotto E, Popa M, Stanciulea O, Fernandez MH, Tulbure D, Bueso-Ramos CE, et al. MicroRNA Fingerprints Identify miR-150 as a Plasma Prognostic Marker in Patients with Sepsis. Plos One. 2009; 4: e7405. doi: 10.1371/journal.pone.0007405.

29. Concepcion CP, Bonetti C, Ventura A. The MicroRNA-17-92 Family of MicroRNA Clusters in Development and Disease. Cancer J. 2012; 18: 262-7. doi: 10.1097/PPO.0b013e318258b60a.

30. Fedeli M, Riba M, Manteiga JM, Tian L, Vigano V, Rossetti G, Pagani M, Xiao CC, Liston A, Stupka E, Cittaro D, Abrignani S, Provero P, et al. miR-17 similar to 92 family clusters control iNKT cell ontogenesis via modulation of TGF-beta signaling. Proc Natl Acad Sci U S A. 2016; 113: E8286-E95. doi: 10.1073/pnas.1612024114.

31. Wu TQ, Wieland A, Araki K, Davis CW, Ye LL, Hale JS, Ahmed R. Temporal expression of microRNA cluster miR-17-92 regulates effector and memory CD8(+) T-cell differentiation. Proc Natl Acad Sci U S A. 2012; 109: 996570. doi: 10.1073/pnas.1207327109.

32. Fourie NH, Peace RM, Abey SK, Sherwin LB, RahimWilliams B, Smyser PA, Wiley JW, Henderson WA. Elevated circulating miR-150 and miR-342-3p in patients with irritable bowel syndrome. Exp Mol Pathol. 2014; 96: 422-5. doi: 10.1016/j.yexmp.2014.04.009.

33. Czimmerer Z, Varga T, Kiss M, Vazquez CO, Doan-Xuan QM, Ruckerl D, Tattikota SG, Yan X, Nagy ZS, Daniel B, Poliska S, Horvath A, Nagy G, et al. The IL-4/STAT6 signaling axis establishes a conserved microRNA signature in human and mouse macrophages regulating cell survival via miR-342-3p. Genome Med. 2016; 8: 63. doi: 10.1186/ s13073-016-0315-y.

34. Robertson KA, Hsieh WY, Forster T, Blanc M, Lu HJ, Crick PJ, Yutuc E, Watterson S, Martin K, Griffiths SJ, Enright AJ, Yamamoto M, Pradeepa MM, et al. An Interferon Regulated MicroRNA Provides Broad CellIntrinsic Antiviral Immunity through Multihit HostDirected Targeting of the Sterol Pathway. PLoS Biol. 2016; 14: e1002364. doi: 10.1371/journal.pbio.1002364.
35. Ioannidis I, McNally B, Willette M, Peeples ME, Chaussabel D, Durbin JE, Ramilo O, Mejias A, Flano E. Plasticity and Virus Specificity of the Airway Epithelial Cell Immune Response during Respiratory Virus Infection. J Virol. 2012; 86: 5422-36. doi: 10.1128/jvi.06757-11.

36. Kurt-Jones EA, Popova L, Kwinn L, Haynes LM, Jones LP, Tripp RA, Walsh EE, Freeman MW, Golenbock DT, Anderson LJ, Finberg RW. Pattern recognition receptors TLR4 and CD14 mediate response to respiratory syncytial virus. Nat Immunol. 2000; 1: 398-401. doi: 10.1038/80833.

37. Haynes LM, Moore DD, Kurt-Jones EA, Finberg RW, Anderson LJ, Tripp RA. Involvement of toll-like receptor 4 in innate immunity to respiratory syncytial virus. J Virol. 2001; 75: 10730-7. doi: 10.1128/jvi.75.22.1073010737.2001 .

38. Tal G, Mandelberg A, Dalal I, Cesar K, Somekh E, Tal A, Oron A, Itskovich S, Ballin A, Houri S, Beigelman A, Lider O, Rechavi G, et al. Association between common Toll-like receptor 4 mutations and severe respiratory syncytial virus disease. J Infect Dis. 2004; 189: 2057-63. doi: 10.1086/420830.

39. Becker Y. Respiratory syncytial virus (RSV) evades the human adaptive immune system by skewing the Th1/Th2 cytokine balance toward increased levels of Th2 cytokines and IgE, markers of allergy - a review. Virus Genes. 2006; 33: 235-52. doi: 10.1007/s11262-006-0064-x.

40. Thornburg NJ, Shepherd B, Crowe JE. Transforming Growth Factor Beta Is a Major Regulator of Human Neonatal Immune Responses following Respiratory Syncytial Virus Infection. J Virol. 2010; 84: 12895-902. doi: 10.1128/jvi.01273-10.

41. Zambrano-Zaragoza JF, Romo-Martínez EJ, Durán-Avelar Mde J, García-Magallanes N, Vibanco-Pérez N. Th17 Cells in Autoimmune and Infectious Diseases. Int J Inflam. 2014; 2014: 651503. doi: 10.1155/2014/651503. 